\title{
Effect of blanching on physicochemical characteristics of potato flour
}

\author{
Revenli Fernanda do Nascimento; Maria Helene G Canteri ${ }^{1}$
}

${ }^{1}$ Universidade Tecnológica Federal do Paraná (UTFPR), Ponta Grossa-PR, Brazil; revenli_fernanda@hotmail.com; canteri@utfpr.edu.br

\begin{abstract}
Offering new products obtained from potatoes is a market opportunity which may increase and motivate the consumption of this tuber. It also can contribute for waste reduction and ensure market for growers. Thus, we aimed to produce potato flour and to evaluate the effect of blanching on the physiochemical characteristics of this product after 3-month storage at room temperature. Potatoes cultivar Agata were used to make unblanched and blanched flour, through thermal treatment at $97^{\circ} \mathrm{C}$ for $5 \mathrm{~min}$. The unblanched potato flour presented significantly smaller contents of moisture $(p=0.006)$, proteins $(\mathrm{p}=0.001)$ and soluble fibers $(\mathrm{p}=0.024)$, as well as color alteration. However, it presented higher phenolic compound content $(23.77 \%)$. The blanched potato flour presented similar nutritional quality compared with the raw potato flour, and also longer shelf life, since dehydration can reduce about $95 \%$ of the initial moisture content of the potato. The thermal treatment (blanching) improved the supply of proteins and soluble fibers of the final product, as well as prevented enzymatic browning reaction which would result in color alteration of the product. The treatment reduced total phenolic compound content, though.
\end{abstract}

Keywords: Solanum tuberosum, color, physicochemical properties, phenolic compounds, thermal treatment.

\section{RESUMO}

Efeito do branqueamento nas características físico-químicas de farinha de batata

A oferta de novos produtos a partir da batata é uma oportunidade de mercado que pode aumentar e incentivar o consumo deste tubérculo, contribuir para a redução do desperdício e garantir mercado para os agricultores. Desta forma, o presente trabalho teve por objetivo produzir uma farinha de batata e avaliar o efeito do branqueamento sobre as características físico-químicas desse produto após três meses de armazenamento em temperatura ambiente. Para o desenvolvimento do trabalho, batatas da cultivar Ágata foram utilizadas para produção de farinha não branqueada e branqueada, por meio de tratamento térmico $97^{\circ} \mathrm{C}$ por $5 \mathrm{~min}$. A farinha de batata não branqueada apresentou teores significativamente menores de umidade $(\mathrm{p}=0,006)$, proteínas $(p=0,001)$ e fibras solúveis $(p=0,024)$, bem como alteração da coloração. No entanto, apresentou conteúdo de composto fenólicos superior em $23,77 \%$. A farinha de batata branqueada apresentou qualidade nutricional semelhante à batata in natura, associada ao prolongamento da vida útil, visto que a desidratação pode reduzir cerca de $95 \%$ da umidade inicial da batata. O tratamento térmico (branqueamento) melhorou o aporte de proteínas e fibras solúveis do produto final, bem como impediu a reação de escurecimento enzimático que levaria à alteração da cor da farinha, no entanto, reduziu o teor de compostos fenólicos totais.

Palavras-chave: Solanum tuberosum, tratamento térmico, propriedades físico-químicas, compostos fenólicos, cor.

\section{Received on October 17, 2017; accepted on September 11, 2018}

$\mathrm{P}$ otato (Solanum tuberosum) is one of the most consumed vegetables and it is accessible to all social classes. This food can be easily prepared and it has a high nutritional value (Lovat et al., 2016). For these reasons, potato has become the third most important food crop worldwide, third only to wheat and rice (Yamdeu et al., 2016). In 2017, Brazil produced over 4.2 million tons of potatoes, with an increase of $9.3 \%$ comparing with the previous year, showing an average yield of $30.8 \mathrm{tha}^{-1}$ (IBGE, 2017).

During harvest, commercialization and processing, great quantities are lost causing substantial economic loss for growers and waste of precious food, because of inefficient post-harvest management, mechanical injuries, market demands for lighter color tubers after washing and with the minimum of external defects, bad distribution and inappropriate storage facilities (Rafiq \& Ghosh, 2017). Guerra et al. (2014) noticed that $13.12 \%$ of potatoes commercialized in retail market, in Santarem-PA, were discharged since they showed some kind of damage; $73 \%$ of theses damages were considered mechanic damages. Besides these, potato tubers have limited lifespan, resulting in large losses due to delays in retail sales, since in Brazil most of the production is destined to fresh consumption.

Thus, the supply of new products made from fresh potatoes is a great market opportunity to be exploited in order to increase and motivate the consumption, besides contributing to reduce waste and to ensure growers' market (Rafiq \& Ghosh, 2017). Potato flour production is a simple process that, differently from potato starch, 
corresponds to the starch product extracted from this tuber; the flour is elaborated using the whole potato tubers, in some formulations even the potato peel is used (ANVISA, 1978). Therefore, besides aggregating value to tubers which would be discarded, potato flour provides the consumer market with a new product with nutritional quality of the fresh potato, associated with longer shelf life. Additionally, this flour can be used both as food to be consumed directly and raw material for other product preparation, such as loaves of bread, cakes, appetizers, cookies, among others (Lovat et al., 2016).

Thermal treatment (blanching) before the processing of potato tubers aims to inactivate enzymes and microorganisms which cause deterioration, in order to increase quality and useful life of processed foods during storage. One of the main inactivated enzymes through blanching is polyphenoloxidase (PPO), which causes enzymatic browning of fruits and vegetables, responsible for changes in texture, color, odor, taste and nutritional quality (Araújo, 2008).

Given the above, this work aims to produce potato flour and evaluate the effect of blanching on physicochemical characteristics of this product.

\section{MATERIAL AND METHODS}

The authors used $2.2 \mathrm{~kg}$ of potatoes cultivar Agata (raw material), from the November (planting) to January (harvest) of 2017 season, cultivated by growers in the Region of Campos Gerais do Paraná. Washed tubers were provided by a vegetable processing company of Parana State, after 7-day storage at $9-10^{\circ} \mathrm{C}$ controlled temperature and $80-$ $85 \%$ relative humidity.

In order to produce unblanched flour (UB), $1.1 \mathrm{~kg}$ of potatoes were washed, peeled, grated and then taken into a dryer with forced air circulation at $45^{\circ} \mathrm{C}$ for 24 hours, or until reaching constant mass and then, crushed in a blender until obtaining a fine and homogeneous powder. To produce blanched flour (BC), after being washed, the rest of potatoes was immersed into water at $97^{\circ} \mathrm{C}$ for $5 \mathrm{~min}$ and cooled in water-ice bath $\left(4^{\circ} \mathrm{C}\right)$. Afterwards, $\mathrm{BC}$ followed the same process used to obtain UB flour.

Blanched and unblanched flours were stored in airtight bottles, in a dry, dark place, at room temperature during three months.

\section{Physicochemical analysis}

Physicochemical analyses were carried out in laboratories of Departamento de Alimentos of UniversidadeTecnológica Federal do Paraná, Campus Ponta Grossa, Brazil. Humidity, ashes, proteins, lipids and fibers (insoluble and soluble) were analyzed following the methodology suggested by AOAC (2005), methods 925.10, 923.03, 945.18-B, 922.06 and 991.43, respectively. Analyzes were performed in triplicate. Carbohydrate content (\%) was determined by difference, 100 - $($ ash + lipid + protein + fiber).

Total phenolic compounds were determined using Folin-Ciocalteu method according to the methodology by Lombardo et al. (2013) with the following modifications: to extract total phenolic compounds $5 \mathrm{mg}$ of sample were mixed with ethanol $(10 \mathrm{~mL} 80 \%$ $\mathrm{v} / \mathrm{v}$ ), remaining at 24 -hour rest. Then, the authors extracted $0.3 \mathrm{~mL}$ of the supernatant from each extract obtained and $3.3 \mathrm{~mL}$ of Folin-Ciocalteu $(10 \%$ $\mathrm{v} / \mathrm{v}$ ) were added and $2.4 \mathrm{~mL}$ of sodium carbonate $(7,5 \% \mathrm{~m} / \mathrm{v})$. Absorbance was measured at $760 \mathrm{~nm}$ using a UV-Vis spectrophotometer (Femto 800 XI). Phenolic compound content was determined based on a standard calibration curve generated with known amounts of tannic acid (TAN)/g dry weight of potato flour (Figure 1).

The evaluation of the instrumental color was carried out directly in the potato flour, with the aid of a colorimeter (Hunter Lab Ultra Scan Pro). CIE L* a* $b^{*}$ color-space coordinates and $C^{*}$ index were evaluated. $L^{*}$ value represents luminosity of color stimulation, ranging from zero (black) to 100 (white), $a^{*}$ ranging from green $(-60)$ to red $(+60), b^{*}$ ranging from blue (-60) to yellow $(+60)$ and $\mathrm{C}^{*}$ representing chroma relating to color intensity (Buckley \& Giorgianni, 2015).

\section{Statistical analysis}

Statistical treatments of these data were performed using SPSS $23^{\circledR}$ software. Levene and KolmogorovSmirnov tests were applied in order to verify variance homogeneity and normal distribution of data, respectively.

Considering that no homogeneous data was noticed (Levene's test: $\mathrm{p}>0.05$ ), as well as no normal data was verified either (Kolmogorov-Smirnov's test: $\mathrm{p}>0.05$ ), variance analysis (ANOVA) was performed to differentiate groups considering $95 \%$ confidence level $(\mathrm{p} \leq 0.05)$ using a completely randomized design, with three replicates. The results were expressed as averages \pm standard deviation.

\section{RESULTS AND DISCUSSION}

Potato flour yields, UB and BC, were from 8 to $9 \%$, respectively ( $\mathrm{p}=0.005)$, possibly the highest yield of $\mathrm{BC}$ flour is associated to the highest moisture content. Santos (2009) reported in

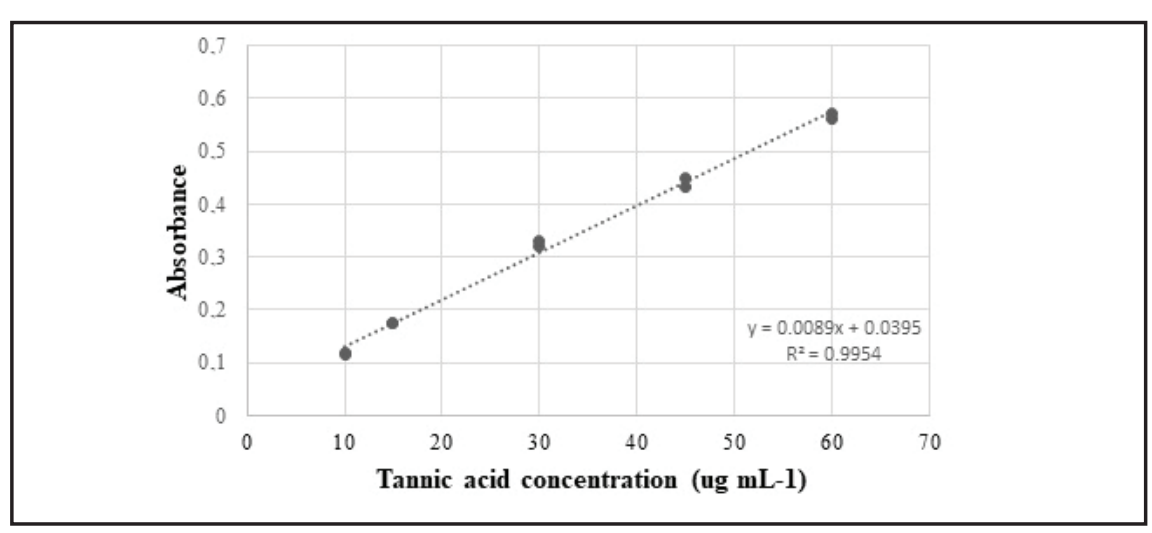

Figure 1. Standard calibration curve generated using tannic acid. Ponta Grossa, UTFPR, 2018. 
Table 1. Physiochemical characterization of potato flours. Ponta Grossa, UTFPR, 2018.

\begin{tabular}{lccc}
\hline Determinations & UB & BC & p \\
\hline Moisture (\%) & $3.25 \pm 0.11$ & $4.48 \pm 0.38$ & 0.006 \\
Ashes (\%) & $6.95 \pm 0.83$ & $6.91 \pm 0.48$ & 0.065 \\
Proteins (\%) & $1.70 \pm 0.01$ & $2.40 \pm 0.06$ & 0.001 \\
Lipids(\%) & $0.69 \pm 0.08$ & $0.62 \pm 0.07$ & 0.337 \\
Insoluble fibers (\%) & $6.28 \pm 0.36$ & $4.06 \pm 0.42$ & 0.002 \\
Soluble fibers (\%) & $1.33 \pm 0.21$ & $1.82 \pm 0.10$ & 0.024 \\
Carbohydrates (\%) & $83.02 \pm 1.04$ & $80.67 \pm 1.50$ & 0.090 \\
Total phenolic compounds (TAN/g) & $1.43 \pm 0.01$ & $1.09 \pm 0.02$ & 0.001 \\
\hline
\end{tabular}

$\mathrm{UB}=$ unblanched potato flour; $\mathrm{BC}=$ blanched potato flour. $\mathrm{p}<0.05$ shows statistical difference at a $5 \%$ significance level.

Table 2. Instrumental color evaluation of potato flours. Ponta Grossa, UTFPR, 2018.

\begin{tabular}{lccc}
\hline Coordinates & UB & BC & p \\
\hline $\mathrm{L}^{*}$ & $46.72 \pm 0.02$ & $55.29 \pm 0.01$ & 0.001 \\
$\mathrm{a}^{*}$ & $2.69 \pm 0.03$ & $1.24 \pm 0.02$ & 0.001 \\
$\mathrm{~b}^{*}$ & $8.20 \pm 0.01$ & $6.09 \pm 0.03$ & 0.002 \\
$\mathrm{C}^{*}$ & $8.63 \pm 0.01$ & $6.22 \pm 0.03$ & 0.002 \\
\hline
\end{tabular}

$\mathrm{UB}=$ unblanched potato flour; $\mathrm{BC}=$ blanched potato flour. $\mathrm{p}<0.05$ shows statistical difference at a $5 \%$ significance level.

his study yield of $13 \%$ for flour made with Agata potato, higher comparing with this study probably due to higher moisture content of the final product.

Moisture content of $\mathrm{BC}$ potato flour was significantly superior $(\mathrm{p}=0.006)$ comparing with UB flour, probably due to the water absorbed by the potato used for producing the first flour during thermal treatment (Table 1). Higher value was reported by Kaur et al. (2016) for flour made using potato cultivar Kufri Pukhraj, which showed 13.07\% moisture. Santos (2009) mentioned moisture content of approximately $90 \%$ for raw potato cultivar Agata. Thus, this information allowed inferring that the dehydration process used in this study could produce flours with a reduction of initial moisture content of about $95 \%$, which is extremely relevant to ensure longer shelf life, since water activity above 0.9 contributes to bacteria development, and above 0.7 to development of molds and yeasts, as well as intensifies the enzymatic activity (Schultz, 2016).

Values found for ash contents are related to mineral content in potato flour, considering that the main minerals found were potassium, phosphorus, calcium, iron and magnesium (Shin et al., 2015). UB and BC potato flours studied in this experiment had not presented significant differences for mineral content $(\mathrm{p}=0.065)$, showing 6.95 and $6.91 \%$, respectively. Leivas et al. (2013) reported an average of $4.56 \%$ of minerals in potato flour made from cultivar Agata. Mineral content variation in potatoes may be attributed to conditions of growing and fertilization, as this crop is highly influenced by nutrients added to soil (Zörba et al., 2014). Quadros et al. (2009) carried out a study which showed that potato tubers tend to increase ash content when potassium dose is increased during fertilization.

In relation to proteins, $\mathrm{BC}$ potato flour showed larger quantity $(p=0.001)$ when comparing to UB flour. According to Escaramboni et al. (2013), the proteases, which hydrolyze peptide bonds of the proteins, lose their catalytic activity at temperatures above $70^{\circ} \mathrm{C}$. Thus, remaining proteolytic enzymes and still active in UB potato flour may have caused the reduction of this component. Similar result found in BC potato flour was reported by Garmus et al. (2009) for potato peel flour, which showed $2.46 \%$ proteins.

Potatoes are considered to be a low-fat food, generally between 0.02 and $0.96 \%$, depending on the cultivar (Leivas et al., 2013). Corroborating this statement, potato flours showed in this study $0.69 \%$ and $0.62 \%(p=0.337)$ for $\mathrm{UB}$ and $\mathrm{BC}$ flour, respectively. Virmond et al. (2014), studying physicochemical characteristics of flour made of potatoes, cultivar Agata, Atlantic and BRS Clara, reported $0.09 \%, 0.09 \%$ and $0.11 \%$ of lipids, respectively.

The value found for insoluble fibers in UB potato flour $(6.28 \%)$ was higher $(\mathrm{p}=0,002)$ than in $\mathrm{BC}$ flour $(4.06 \%)$, whereas the opposite was found for soluble fibers $(p=0.024)$, with average contents of $1.33 \%$ for UB flour and $1.82 \%$ for $\mathrm{BC}$ flour. According to Araújo (2008), enzymatic browning reaction results from phenolic compound oxidation caused by PPO and peroxidase (POD) enzymes, resulting in quinone formation, which rapidly condenses into dark insoluble pigments called melanins. Thus, PPO and POD enzymes which remain in UB flour, probably caused melanin formation, which could be quantified as insoluble fibers, increasing the content of this compound in the flour in this study. Due to the enzymatic inactivation by thermal treatment, the pectinolytic enzymes, which degrade pectin, soluble fiber present in fruits and vegetables, also lose their activity. That is the reason why, active enzymes in flour without any thermal treatment could have reduced the soluble fibers. Nascimento \& Canteri (2016) reported similar results for UB and BC sweet potato flour, which showed $15.08 \%$ and $7.17 \%$ of insoluble fibers and $2.46 \%$ and $4.13 \%$ of soluble fibers, respectively.

Thermal treatment did not significantly affect $(p=0.09)$ carbohydrate content of the studied flours, with an average of $81 \%$. This high carbohydrate content is mainly due to the presence of starch, $60-80 \%$ (Murniece et al., 2011). Similar results were mentioned by Leivas et al. (2013), 
$82.49 \%$ and $80.84 \%$ of carbohydrates in flours made using potato cultivars Agata and Cristina, respectively. TrancosoReyes et al. (2016) found 87\% of carbohydrates in sweet potato flour, higher values comparing with the ones reported for potato flour.

Potatoes are a good source of phenolic compounds: the main ones are phenolic acids and flavonoids, including flavonols and anthocyanins (Akyol et al., 2016). Total phenolic compound content in UB potato flour was higher $(p=0.001)$ than in $B C$ flour, probably the thermal process used corroborate the reduction of total phenolic, since quantity and stability of these compounds are differently associated with processing thermal conditions (Lemos et al., 2014; Siroha \& Sandhu, 2017). Moreover, the absence of phenylalanine-ammonia-lyase (PAL), which can be inactivated by thermal processing could also have collaborated with the reduction of total phenolic compounds in $\mathrm{BC}$ potato flour, taking into consideration that such enzyme is involved in total phenolic processing metabolism (Cantos et al., 2002). The mechanical stress caused by the processing in cellular tissue of the plants results in an increase of the activity of the enzyme PAL (Palharini et al., 2015), causing an increase in the concentration of phenolic compounds (Cantos et al., 2002).

$\mathrm{L}^{*}$ value of UB potato flour was smaller $(p=0,001)$ than in BC flour (Table 2), showing that this flour remained darker, in relation, mainly, to the presence of PPO and POD enzymes, which are responsible for the enzymatic browning reaction, which lead to formation of dark compounds (Araújo, 2008). Although both flours present color closer to red, the authors noticed that $\mathrm{a}^{*}$ value of UB flour was higher $(p=0.001)$ than in $B C$, possibly due to enzymatic browning, since this reaction initiated with reddish color (Lovatto et al., 2012). Identically, b* and $C^{*}$ values of UB flour was higher $(\mathrm{p}=$ 0.002) than $\mathrm{BC}$ flour, showing that this flour remained yellow and with higher color intensity. According to Goyeneche et al. (2014), these results are related to browning reaction.
Process of producing potato flour, besides aggregating value to tubers which would be discarded, provides a new product with nutritional quality of fresh potato, associated with longer shelf life, considering that dehydration may reduce $95 \%$ of potato initial moisture. Additionally, blanching process improved the supply of proteins and soluble fibers of the final product, as this thermal treatment is able to inactivate enzymes, such as proteases and pectinases, besides PPO and POD; prevented enzymatic browning reaction which would result in color alteration of flour; however, this process reduced total phenolic compound content.

\section{ACKNOWLEDGEMENTS}

The authors thank Coordination of Improvement of Higher Education Personnel (CAPES) for the financial support for postgraduate studies in the area of Production Engineering.

\section{REFERENCES}

AKYOL, H; RICIPUTI, Y; CAPANOGLU, E; CABONI, MF; VERARDO, V. 2016. Phenolic compounds in the potato and its byproducts: an overview. International Journal of Molecular Sciences 17: 835-853.

ANVISA. 1978. Agência Nacional de Vigilância Sanitária: Resolução-CNNPA n ${ }^{\circ} 12$, de 1978. p 21-24.

AOAC. 2005. Official methods of analysis of AOAC international. Washington: AOAC.

ARAÚJO, JMA. 2008. Química de alimentos. Viçosa: UFV. p389-391.

BUCKLEY, RR; GIORGIANNI, EJ. 2015. Encyclopedia of color science and technology. Berlin Heidelberg: Springer. p 1-9.

CANTOS, E; TUDELA, JÁ; GIL, MI; ESPÍN, JC. 2002. Phenolic compounds and related enzymes are not rate-limiting in browning development of fresh-cut potatoes. Journal of Agricultural and Food Chemistry 50: 3015-3023.

ESCARAMBONI, E; SILVA, DF; NETO, PO. 2013. Influência da temperatura na atividade de amilase e protease de Rhizopus oligosporus cultivado por fermentação em estado sólido. Biochemistry and Biotechnology Reports 2: 285-288.

GARMUS, TT; BEZERRA, JRMV; RIGO, M; CÓRDOVA, KRV. 2009. Elaboração de biscoitos com adição de farinha de casca de batata (Solanum tuberosum L.). Revista Brasileira de Tecnologia Agroindustrial 3: 56-65.
GOYENECHE, R; AGÜERO, MV; ROURA, S; SCALA, KD. 2014. Application of citric acid and mild heat shock to minimally processed sliced radish: color evaluation. Postharvest Biology and Technology 93: 106-113.

GUERRA, AMN; FERREIRA, JBA; COSTA, ACM; TAVARES, PRF. 2014. Causas de perdas pós colheita em cenoura e batata no mercado varejista de Santarém-PA. Revista Tecnologia e Ciência Agropecuária 8: 61-68.

IBGE. 2017. Brazilian Institute of Geography and Statistics. Rio de Janeiro: IBGE. 93p.

KAUR, A; KOCHHAR, A; PRASAD, P. 2016. Nutritional evaluation of value added products using potato flour. International Journal of Health Sciences and Research 6: 466-472.

LEIVAS, CL; COSTA, FJOG; ALMEIDA, RR; FREITAS, RJS; STERTZ, SCS; SCHNITZLER, E. 2013. Structural, physicochemical, thermal and pasting properties of potato (Solanum tuberosum L.) flour. Journal of Thermal Analysis and Calorimetry 111: 2211-2216.

LEMOS, M; ALIYU, M; HUNGERFORD, G. 2014. Influence of cooking on the levels of bioactive compounds in purple majesty potato observed via chemical and spectroscopic means. Food Chemistry 173: 462-467.

L O M B AR D O, S ; PAN D IN O, G; MAUROMICALE, G. 2013. The influence of growing environment on the antioxidant and mineral content of "early" crop potato. Journal of Food Composition and Analysis 32: 28-35.

LOVAT, C; NASSAR, AMK; KUBOW, S; LI, XQ; DONNELLY, DJ. 2016. Metabolic biosynthesis of potato (Solanum tuberosum L.) antioxidants and implications for human health. Critical Reviews in Food Science and Nutrition 56: 2278-2303.

LOVATTO, MT; BISOGNIN, DA; TREPTOW, RO; STORCK, L; GNOCATO, FS; MORIN JUNIOR, G. 2012. Processamento mínimo de tubérculos de batata de baixo valor comercial. Horticultura Brasileira 30: 258-265.

MURNIECE, I; KARKLINA, D; GALOBURDA, R; SANTARE, D; SKRABULE, I; COSTA, HS. 2011. Nutritional composition of freshly harvested and stored Latvian potato (Solanum tuberosum L.) varieties depending on traditional cooking methods. Journal of Food Composition and Analysis 24: 699-710.

NASCIMENTO, RF; CANTERI, MHG. 2016. Modificação das fibras dietéticas no armazenamento de vegetais sem tratamento térmico. Revista Brasileira de Produtos Agroindustriais 18: 423-426.

PALHARINI, MCA; SANTOS, CAJP; SIMIONATO, EMRS; KODAWARA, RK; KLUGE, RA. 2015. Dióxido de cloro no controle da microbiota e do escurecimento enzimático de vagem minimamente processada. Horticultura Brasileira 33: 181-188.

QUADROS, DA; IUNG, MC; FERREIRA, SMR; FREITAS, RJS. 2009. Composição química de tubérculos de batata para processamento, cultivados sob diferentes doses e fontes de potássio. Ciência e Tecnologia de Alimentos 29: 316-323.

RAFIQ, SM; GHOSH, BC. 2017. Effect of 
potato incorporation on the physico-chemical, textural and sensory properties of processed cheese. Journal of Food Measurement and Characterization 11: 776-780.

SANTOS, AP. 2009. Farinha de batata (Solanum tuberosum L.): obtenção, caracterização físico-química, funcional, elaboração e caracterização de sopas desidratadas. Itapetinga: UESB. 105p (MSc. thesis).

SCHULTZ, C. 2016. Water activity as related to microorganisms in the manufacturing environment. General Internal Medicine and Clinical Innovations 1: 1-2.

SHIN, EH; BAIK, MY; KIM, HS. 2015. Comparison of physicochemical properties of starches and parenchyma cells isolated from potatoes cultivated in Korea. Food Science and Biotechnology 24: 955-963.

SIROHA, AK; SANDHU, KS. 2017. Effect of heat processing on the antioxidant properties of pearl millet (Pennisetum glaucum L.) cultivars. Journal of Food Measurement and Characterization 11: 872-878.

TRANCOSO-REYES, N; OCHOA-MARTÍNEZ, LA; BELLO-PÉREZ, LA; MORALESCASTRO, J; ESTÉVEZ-SANTIAGO, R; OLMEDILLA-ALONSO, B. 2016. Effect of pre-treatment on physicochemical and structural properties, and the bioaccessibility of $\beta$-carotene in sweet potato flour. Food Chemistry 200: 199-205.

VIRMOND, EP; KAWAKAMI, J; VONCIK, KS;
CÓRDOVA, KRV; SLOMPO, PJH. 2014. Características físico-químicas de cultivares de batata sob cultivo orgânico. Ambiência 10: $31-42$.

YAMDEU, JHG; GUPTA, PH; PATEL, NJ; SHAH, A; TALATIJ, G. 2016. Effect of storage temperature on carbohydrate metabolism and development of cold-induced sweetening in Indian potato (Solanum tuberosum L.) varieties. Journal of Food Biochemistry 40: 71-83.

ZÖRBA, C; SENBAYRAMB, M; PEITER, E. 2014. Potassium in agriculture - Status and perspectives. Journal of Plant Physiology 171:656-669.. 